\title{
Effects of Spatial Expansion Between Phragmites Australis And Cyperus Malaccensis On Temporal Variations And Bioaccumulation of Vanadium In Coastal Marshes of The Min River Estuary, Southeast China
}

\section{Shaohui Yao}

South China Sea Institute of Oceanology Chinese Academy of Sciences

Zhigao Sun ( $\nabla$ zhigaosun@163.com )

Fujian Normal University Cangshan Campus: Fujian Normal University https://orcid.org/0000-0001-7970-1376

Yajin Li

Fujian Normal University Cangshan Campus: Fujian Normal University

Xiao Li

Fujian Normal University Cangshan Campus: Fujian Normal University

\section{Research Article}

Keywords: Vanadium bioaccumulation, Temporal variation, Spatial expansion, Coastal marsh, Min River estuary

Posted Date: September 20th, 2021

DOI: https://doi.org/10.21203/rs.3.rs-879576/v1

License: @ (i) This work is licensed under a Creative Commons Attribution 4.0 International License. Read Full License

Version of Record: A version of this preprint was published at Wetlands on March 16th, 2022. See the published version at https://doi.org/10.1007/s13157-022-01542-w. 


\section{Abstract}

Vanadium (V) plays important roles in physio-ecological processes of marsh plants. To investigate the effects of spatial expansion between native invasive species (Phragmites australis, PA) and common native species (Cyperus malaccensis, $\mathrm{CM}$ ) on temporal variations and bioaccumulation of $\mathrm{V}$ in coastal marshes of the Min River estuary, in situ filed sampling was conducted in PA marsh (PAM, before expansion), CM marsh (CMM, before expansion) and ecotonal marsh (EM, during expansion, marsh plants were denoted by PA' and CM') at different seasons by space-for-time substitution method. Results showed that, over all sampling seasons, the mean $V$ contents in marsh soils ranged from 99.71 to $108.41 \mathrm{mg} \cdot \mathrm{kg}^{-1}$ which exceeded its background value in soils of Fujian province (78.3 $\left.\mathrm{mg} \cdot \mathrm{kg}^{-1}\right)$. The $\mathrm{V}$ levels in soils differed among seasons or marshes. Higher $\mathrm{V}$ contents in soils of PAM, EM and CMM generally occurred in spring and winter. Over all sampling seasons, the $\mathrm{V}$ levels in profiles of EM were much higher than those of PAM and CMM. The temporal variation of $\mathrm{V}$ levels in soils of $\mathrm{EM}$ might rest with the alterations of soil $\mathrm{pH}, \mathrm{SOM}$ and plant ecological traits during the spatial expansion. Although the $V$ contents in PA, PA', CM' and CM differed among tissues, both the roots/stems (R/S) and roots/leaves (R/L) ratios were larger than 1 while the stems/leaves $(\mathrm{S} / \mathrm{L})$ ratios were less than 1, implying that the values in roots were much higher than those in other tissues. The $V$ levels in tissues differed among species or seasons, which could be interpreted by the differences in ecological traits among plants and the competitive absorption for $\mathrm{V}$ by plants during the spatial expansion. Allocations of $\mathrm{V}$ in organs differed among seasons or species and roots were the main $V$ stock of plant subsystems. This paper found that the $V$ in soils of the Min River estuary existed enrichment process and the spatial expansion between PA and CM promoted its enrichment in soils and its bioaccumulation by plants.

\section{Introduction}

Vanadium (V) is vital beneficial element, which play important roles in many physio-ecological processes of marsh plants (Zhu et al., 2016). Similar to molybdenum (Mo), V is indispensible beneficial element which not only can promote the biological fixation of nitrogen but also can enhance the absorption and utilization of iron $(\mathrm{Fe})$ by plants and eventually influence on the biosynthesis of chlorophyll (Wang and Wei, 1995; Nawaz et al., 2018). However, excessive amount of V might inhibit the adenosine triphosphatase in cell membrane of roots, retard the growth of marsh plants and reduce the absorption of calcium and phosphate by plants (Jiao and Teng, 2008). Marsh soil is the key $\mathrm{V}$ stock and the $\mathrm{V}$ bioaccumulation by plants not only reflects its bioavailability in soils but also indicates its biogeochemical behaviors in marsh ecosystem (Li et al., 2020a).

Coastal marsh is one of the most sensitive ecosystems where the material-energy exchanges between fluvial ecosystem and marine ecosystem generally occur (Simas et al., 2001). As affected by the mixing of freshwater and seawater, the physico-chemical conditions in environmental medium (e.g., temperature, grain particle, salinity, $\mathrm{pH}$ and redox) are greatly and frequently changed (Moran et al., 1996). The coastal marsh is also affected by severe hydrodynamic forces, frequent erosion and deposition and high intensity human activities. All these induce the enrichment and biogeochemical processes of elements in coastal marsh are very complicated (Sun et al., 2017). In the past decade, there has been an ever-increasing interest in discussing the distribution and storage of biogenic elements (e.g., C, N, P and S) (Korol et al., 2016; Herbert et al., 2018; Wan et al., 2020; He et al., 2020) and heavy metals (e.g., Pb, Cu, Zn, Cr and $\mathrm{Ni}$ ) (Chen \& Ma, 2017; Keshta et al., 2020) in plant-soil system of coastal marshes, while information on bioaccumulation of beneficial elements (e.g., $\mathrm{V}$ and $\mathrm{Co}$ ) by plants in coastal marsh is poorly documented.

The Min River estuary, located in the transition region of mid-subtropical zone and south subtropical zone, is one of the biggest rivers flowing into the East China Sea in the Fujian Province of southeast China. The marshes in the Min River estuary distribute along the riverbank or estuary and start from Zhuqi in the west and end in Chuanshi Island in the east, with a total area of $980.6 \mathrm{~km}^{2}$ (Liu et al. 2006). Shanyutan is the largest marsh in the Min River estuary, where Scirpus triqueter, Phragmites australis, Cyperus malaccensis and Cyperus compressus are the most common native plants. Thereinto, $P$. australis and $C$. malaccensis are two dominant vegetations which are widely distributed in intertidal zone. Local historical records showed that $P$. australis (a native invasive species) first colonized the Shanyutan at about $30 \sim 40$ years ago due to its dispersal from middle and upper reaches of the Min River (Tong et al., 2011). Thereafter, the marsh originally dominated by $C$. malaccensis is gradually occupied by $P$. australis, resulting in which becomes a single dominant community or even forms an ecotonal community with $C$. malaccensis (approximately $100 \sim 120$ meter-wide). The spatial expansion between $P$. australis and $C$. malaccensis actually reflects the competitions of the two species for environmental resources such as light, water and nutrient (Li et al. 2020b). Existing studies have indicated that the spatial expansion of dominant species not only greatly altered the sedimentary environment and the physical or chemical conditions of marsh ecosystem (Ewanchuk et al., 2004), but also significantly influenced the ecological traits of plants and the key biogeochemical processes of elements by exert

Page 2/20 
strong effects on biotic and abiotic variables of marsh (Zhang et al. 2010; Vilà et al. 2011). As jointly affected by hydrodynamic forces, tide and community succession, the biotic and abiotic conditions in ecotonal marsh of the Min River estuary might be more complex (Li et al., 2020a), which directly or indirectly influences the distribution, storage and biogeochemical behaviors of elements in plant-soil system. Although considerable efforts have been conducted in the Min River estuary to investigate the levels of biogenic elements in plant-soil systems of different marshes (Wang et al. 2018; Chen et al. 2018; Zhang et al, 2020), insufficient information is available concerning the bioaccumulation of beneficial elements by plants is still very lacking. Particularly, little is known about the temporal variations of $\mathrm{V}$ bioaccumulation by $P$. australis and $C$. malaccensis during their spatial expansion.

In this paper, the influences of spatial expansion between $P$. australis and $C$. malaccensis on temporal variations and bioaccumulation of $\mathrm{V}$ in coastal marshes of the Min River estuary were investigated by space-for-time substitution method and three typical marshes $(P$. australis, $C$. malaccensis and ecotonal marshes) were studied. It was hypothesed that the temporal variations of $\mathrm{V}$ bioaccumulation in $P$. australis and $C$. malaccensis might be greatly affected by their spatial expansion. Objectives of this paper were: $i)$ to explore the temporal variations of $\mathrm{V}$ levels in soils of different marshes; ii) to investigate the $\mathrm{V}$ bioaccumulation in different plants over all sampling seasons; and iii) to determine the key factors influencing the bioaccumulation and transference of $\vee$ in marsh plants.

\section{Study Region And Methods}

\subsection{Study region}

This study was carried out in intertidal zone of the Shanyutan $\left(26^{\circ} 00^{\prime} 36^{\prime \prime} \mathrm{N} \sim 26^{\circ} 03^{\prime} 42^{\prime \prime} \mathrm{N}, 119^{\circ} 34^{\prime} 12^{\prime \prime} \mathrm{E} \sim 119^{\circ} 40^{\prime} 40^{\prime \prime} \mathrm{E}\right)$, which is located in the south of the Min River estuary (Fig. 1a), with an area of $893 \mathrm{hm}^{2}$ (Zhang et al., 2011). The tide is typical semi-diurnal tide and the mean tidal range is $4.37 \sim 4.46 \mathrm{~m}$ (Dai, 2004). During each tidal inundation, the marsh in intertidal zone is generally submerged for $3 \sim$

$3.5 \mathrm{~h}$. The climate is warm and wet, with a mean annual temperature of $19.6^{\circ} \mathrm{C}$ and a mean annual precipitation of $1350 \mathrm{~mm}$ (Zheng et al., 2006). The marsh soil is dominated by saline soil and the main native vegetations include $P$. australis, $C$. malaccensis, $C$. compressus and S. triqueter.

\subsection{Study methods}

\subsubsection{Sample collection}

The space-for-time substitution method was used to investigate the influence of spatial expansion between $P$. australis and $C$. malaccensis on temporal variations and bioaccumulation of $\mathrm{V}$ in coastal marshes. The $P$. australis (PA) community and $C$. malaccensis (CM) community represented the stage of before expansion, while the $P$. australis- $C$. malaccensis (PA'-CM') community in ecotone represented the stage of during expansion. The elevation and hydrological regime of different communities were similar. Three experimental plots $(50 \mathrm{~m} \times 50 \mathrm{~m}$ ) were randomly laid in intertidal zone of the northwest Shanyutan (Fig. 1b). At each plot, three subplots $(20 \mathrm{~m} \times 20 \mathrm{~m}$ ) were laid in PA marsh (PAM), ecotonal marsh (EM) and CM marsh (CMM), respectively. Field sampling was conducted at above-mentioned subplots in March, July, October and January in 2016, which represented spring, summer, autumn and winter, respectively.

Aboveground and belowground biomasses were determined using quadrat method $(50 \mathrm{~cm} \times 50 \mathrm{~cm})$ at spatial scale in each subplot (three replications). The aboveground part of plants in the quadrat was clipped near the ground and the roots were dug out. The height and density of plants were measured, the roots were washed and the stem, leaf and standing litter were separated carefully. All plant samples were washed thoroughly with deionized water and then were oven-dried at $80{ }^{\circ} \mathrm{C}$ for $48 \mathrm{~h}$. After the measurement of dry weights, the samples were ground into fine powder. Because the substantial roots (>98\%) of $P$. australis and $C$. malaccensis were distributed in 0-60 cm depth (Li et al., 2020a), the V levels in soils of this depth were studied. Three columnar samples $(0-60 \mathrm{~cm})$ were obtained from the same position with plant samples. After the columnar samples were extracted, they were divided at $10 \mathrm{~cm}$ interval. The soil samples were air-dried, ground and sieved through a 100-mesh nylon sieve.

Soil pH and electrical conductivity (EC) in different depths (at $10 \mathrm{~cm}$ interval) were determined in situ by portable pH meter (IQ150, Spectrum, USA) and Soil \& Solution EC meter (Field Scout, Spectrum, USA), respectively. Three single soil cores ( $5.0 \mathrm{~cm}$ diameter) were sampled from each layer and weighed for soil bulk density (BD) and moisture determination after being oven-dried at $105^{\circ} \mathrm{C}$ for $24 \mathrm{~h}$. The physical and chemical properties of topsoil in different marshes of the experimental plots were shown in Table 1.

\subsubsection{Sample analyses}


A $0.0500( \pm 0.0005) \mathrm{g}$ homogenized sample was digested with $2 \mathrm{~mL} \mathrm{HNO} 3(70 \%)$ and $2 \mathrm{~mL} \mathrm{H}_{2} \mathrm{O}_{2}(30 \%)$ at $180^{\circ} \mathrm{C}$ for $15 \mathrm{~h}$. The residue

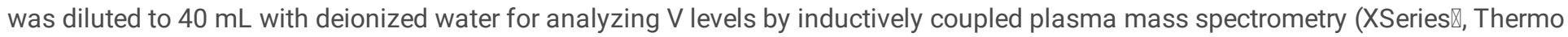
Company, USA). Quality assurance and quality control were assessed using duplicates, method blanks and certified reference materials (GBW10020) from the National Research Center for Standards in China with each batch of samples (two blank and one standard for each 20 samples). The recoveries of samples spiked with standards ranged from 83.2-111.2\%. Soil organic matter (SOM) was determined by soil nutrient analyzer (TFW, Wuhan Tianlian Apparatus Company, China) and soil particle size was analyzed using a laser particle size analyzer (Mastersizer 2000, Malvern Instruments, UK).

\subsubsection{Parameter calculation}

The $V$ stock $\left(T_{V}, \mathrm{mg} \cdot \mathrm{m}^{-2}\right)$ in soil was calculated by the following equation (Wu et al., 2020):

$T_{V}=\sum_{i=1}^{n} B D_{i} \times V_{i} \times h_{i} \times 10$

where $B D_{i}\left(\mathrm{~g}^{\cdot \mathrm{cm}^{-3}}\right)$ is soil bulk density of the $i$ layer; $V_{i}\left(\mathrm{mg} \cdot \mathrm{kg}^{-1}\right)$ is $V$ level in the $i$ layer; and $h_{\mathrm{i}}$ is soil depth $(10 \mathrm{~cm})$.

The $V$ stocks in tissues of plant (root, stem, leaf and standing litter) $\left(V_{i} \mathrm{~g} \cdot \mathrm{m}^{-2}\right)$ were calculated according to Li and Redmann (1992):

$\mathrm{V}_{\mathrm{i}}=\mathrm{C}_{\mathrm{i}} \times \mathrm{B}_{\mathrm{i}}$

where $C_{i}\left(\mathrm{mg} \cdot \mathrm{kg}^{-1}\right)$ is $\vee$ content in the $i$ part; and $B_{i}\left(\mathrm{~g} \cdot \mathrm{m}^{-2}\right)$ is biomass of the $i$ part.

Bioconcentration factors [BCF] in relation to the $\mathrm{V}$ concentrations in soil was calculated by the ratio [Element] plant and [Element] soil (Duman et al. 2007):

$[\mathrm{BCF}]_{\text {root }}=C_{\text {root }} / C_{\text {soil }}$

$[\mathrm{BCF}]_{\text {stem }}=C_{\text {stem }} / C_{\text {soil }}$

$[\mathrm{BCF}]_{\text {leaf }}=C_{\text {leaf }} / C_{\text {soil }}$

$[\mathrm{BCF}]_{\text {litter }}=C_{\text {litter }} / C_{\text {soil }}$

where $C_{\text {root }}, C_{\text {stem }}, C_{\text {leaf }}, C_{\text {litter }}$ and $C_{\text {soil }}$ were the $\mathrm{V}$ concentrations $\left(\mathrm{mg} \mathrm{kg}^{-1}\right)$ in root, stem, leaf, litter and soil, respectively.

The $\mathrm{V}$ concentration quotients for roots/stems (R/S), roots/leaves $(\mathrm{R} / \mathrm{L})$ and stems/leaves $(\mathrm{S} / \mathrm{L})$ were calculated according to Dahmani-Muller et al (2000):

$\mathrm{R} / \mathrm{S}=C_{\text {root }} / C_{\text {stem }}$

$\mathrm{R} / \mathrm{L}=C_{\text {root }} / C_{\text {leaf }}$

$\mathrm{S} / \mathrm{L}=C_{\text {stem }} / C_{\text {leaf }}$

where $C_{\text {root }}, C_{\text {stem }}$ and $C_{\text {leaf }}$ were the same as above.

\subsubsection{Statistical analyses}

Statistical analyses were performed using SPSS 19.0 and Origin 8.5 for Windows. The analysis of variance (ANOVA) test was used to determine if the $\mathrm{V}$ levels in soils differed significantly among seasons (or marshes), or the $\mathrm{V}$ contents in plants differed significantly among seasons (or tissues) $(p<0.05)$. If ANOVA showed significant differences, multiple comparison of means was undertaken by Tukey's test with a significance level of $p=0.05$. The stepwise linear regression analysis was used to best predict the variations of $V$ levels in soils of different marshes based on environmental variables. The principal component analysis (PCA) was used as a first 
exploratory analysis to better visualize the possible environmental gradients determining the variations of $\mathrm{V}$ contents in soils of different marshes. In all tests, differences were considered significant only if $p<0.05$.

\section{Results}

\subsection{Temporal variation of $V$ contents in soils of different marshes}

Dissimilar variations of $\mathrm{V}$ content in soils of different marshes were observed over all sampling seasons (Fig. 2). Higher $\mathrm{V}$ levels in soils of PAM, EM and CMM generally occurred in spring and winter. The $V$ contents in soils of PAM, EM and CMM between spring and winter, between summer and winter, and between autumn and winter showed significant differences $(p<0.05)$. The variations of $V$ levels in soils also differed among marshes (Fig. 2). With a few exceptions, the $\mathrm{V}$ levels in profiles of EM were much higher than those of PAM and CMM. Compared with PAM and CMM, the mean V levels in soils of EM over all sampling seasons increased by $7.2 \%$ and $2.2 \%$, respectively. Significant differences of $\mathrm{V}$ contents in soils of PAM and CMM occurred in spring $(p=0.035)$ and autumn $(p=0.003)$, while those of PAM and EM were observed in summer $(p=0.028)$ and autumn $(p=0.009)$.

\subsection{Temporal variation of $\mathrm{V}$ bioaccumulation by plants}

\subsubsection{Variation of $\mathrm{V}$ contents in plants}

The $\mathrm{V}$ contents in tissues of plants differed among seasons (Fig. 3). The values in roots and leaves of PA or PA' reached the maximums during spring, while those of $\mathrm{CM}$ achieved the highest ones in autumn. By comparison, the $\mathrm{V}$ contents in roots and leaves of $\mathrm{CM}^{\prime}$ reached the maximums during autumn or winter. The highest $\mathrm{V}$ levels in stems of $\mathrm{PA}$ ' and $\mathrm{CM}$ occurred in autumn, whereas those of PA and CM' were observed during winter or spring. The $V$ contents in plants also differed among tissues, and, over all sampling seasons, almost all values in roots of PA, $\mathrm{PA} \mathrm{A}^{\prime}, \mathrm{CM}$ ' and $\mathrm{CM}$ were significantly higher than those in other tissues $(p<0.05)$. The $\checkmark$ levels in tissues of PA' were generally higher than those of PA and, similarly, the values in organs of CM' were much higher than those of $\mathrm{CM}$. With a few exceptions, the $\mathrm{V}$ contents in tissues of $\mathrm{CM}$ ' were higher than those of PA' over all sampling seasons.

\subsubsection{Transfer and accumulation of $V$ in plants}

Dissimilar variations of $R / S, R / L$ and $S / L$ ratios in plants were observed in different seasons (Table 2). The R/S and R/L ratios in PA or $\mathrm{CM}^{\prime}$ reached the maximums in summer, while those in $\mathrm{PA}^{\prime}$ achieved the highest values in spring. The highest $\mathrm{S} / \mathrm{L}$ ratio in $\mathrm{CM}$ and $\mathrm{CM}$ occurred in spring, whereas those in PA and PA' were observed during autumn or winter. With a few exceptions, the R/S and R/L ratios in $\mathrm{PA}^{\prime}$ were lower than those in $\mathrm{PA}$, but the values in $\mathrm{CM}^{\prime}$ were higher than those in $\mathrm{CM}$. Except for spring, the R/S ratios in $\mathrm{CM}^{\prime}$ were higher than those in $P A^{\prime}$ in other seasons. The R/S and R/L ratios in PA, PA', CM' or CM were larger than 1 , while the $S / L$ ratios were less than 1. Over all sampling seasons, the [BCF] in aboveground parts were generally lower than those in roots (Table 3). The [BCF] in roots of $\mathrm{PA}$ and $\mathrm{PA}$ ' reached the maximums in spring, while those of $\mathrm{CM}$ and $\mathrm{CM}^{\prime}$ achieved the highest values in winter.

\subsection{Variation of V stocks and allocations in plant-soil systems}

Similar variations of $\mathrm{V}$ stock in profiles of different marshes were observed over all sampling seasons (Fig. 4). The $\mathrm{V}$ stocks in soils of EM in the four seasons were much higher than those of PAM and CMM. The higher $V$ stocks in soils of PAM, EM and CMM occurred in winter while the lower values were observed during summer or autumn. The $V$ stock in soils was the main body of total stock in plantsoil system (>99\%) (Table 4). Allocations of $V$ in organs differed among seasons or species. Roots were the main $V$ stock of plant subsystems, which achieved the higher values during spring or winter. Allocations of $\mathrm{V}$ in aboveground parts of PA', CM' and CM were the highest in autumn while those of PA reached the maximums in winter.

\section{Discussion}

\subsection{Temporal variations of $\mathrm{V}$ contents in marsh soils}

This paper found that the mean V levels in each layer of marsh soils over all sampling seasons ranged from 99.71 to $108.41 \mathrm{mg} \cdot \mathrm{kg}^{-1}$ which exceeded its background value in soils of Fujian province $\left(78.3 \mathrm{mg} \cdot \mathrm{kg}^{-1}\right)$ (Chen et al., 1992) but was slightly lower than its background value in terrestrial surface of China $\left(112 \mathrm{mg} \cdot \mathrm{kg}^{-1}\right)$ (Nie, 2011), implying that the $\mathrm{V}$ in marsh soils of the Min River estuary existed enrichment process. It was reported that the $\mathrm{V}$ enrichment in soils was mainly dependent on parent material and pedogenesis (Li et al., 2020a), and higher V contents generally occurred in soils originated from parent rock with higher V levels (Wang and Liu, 
1994). Besides, atmospheric deposition and anthropogenic import also influenced the $V$ enrichment in soils (Chen and Sun, 2020a). In this paper, since the study region located in the National Nature Reserve of the Min River estuary which was strictly protected in recent 20 years, the $V$ levels in marsh soil, to a great extent, rested with its geochemical enrichment process.

This paper indicated that the $V$ contents in soils differed among marshes or seasons (Fig. 2), which might rest with the differences in physical and chemical properties of soils in PAM, EM and CMM. The stepwise linear regression analyses showed that the variation of $V$ levels in soils of PAM could be better explained by soil temperature $\left(x_{1}\right)\left(y=-0.93 x_{1}+122.764, R^{2}=0.299, p<0.001\right)$, while those of CMM could be explained by soil temperature $\left(x_{1}\right)$, sand $\left(x_{2}\right)$ and SOM $\left(x_{3}\right)\left(y=-1.093 x_{1}-0.362 x_{2}+1.798 x_{3}+131.3, R^{2}=0.635, p<0.001\right)$. By comparison, the variation of $\mathrm{V}$ contents in soils of $\mathrm{EM}$ could be better explained by $\mathrm{pH}\left(x_{4}\right)$ and $\mathrm{BD}\left(x_{5}\right)\left(y=6.115 x_{4}-101.983 x_{5}+\right.$ $\left.160.575, R^{2}=0.456, p<0.001\right)$. These implied that soil temperature, SOM and $\mathrm{pH}$ might be important factors influencing the temporal variations of $\mathrm{V}$ levels in soils of different marshes. Previous studies have reported that thermal conditions and SOM significantly affected the adsorption-desorption of metallic ions in marsh soils (Boyer et al., 2018; Li et al., 2020c) and higher SOM contents generally favored for enhancing $V$ adsorption due to its strong complexing capacity (Du Laing et al., 2009; Zhu et al., 2016). In this paper, the variations of soil temperature over all sampling seasons could partly explain the temporal variations of $\mathrm{V}$ levels in soils of different marshes. Moreover, the relatively higher SOM contents in EM might also explain its higher V levels in soils (Table 1, Fig. 2). It was also reported that, under acidic condition, metals generally existed in free or ionized state which presented strong mobility (Huang, 2003; Lu and Yan, 2010). The marsh soils in the Min River estuary were acidity and were greatly affected by acid deposition (Pan, 2001; $\mathrm{Li}$ et al., 2020c). Although the $\mathrm{pH}$ in soils of PAM, EM and CMM showed narrow ranges over all sampling seasons (Table 1), the mobility of $\mathrm{V}$ in soils might be increased due to the lower $\mathrm{pH}$ values. This conclusion could partly explain the lower $\mathrm{V}$ levels in soils of PAM since the lower pH were observed (Fig. 2).

This paper implied that the spatial expansion between PA and CM generally increased the $\mathrm{V}$ contents in soils of EM over all sampling seasons (Fig. 2), and, compared with PAM and CMM, the mean values increased by $7.2 \%$ and $2.2 \%$, respectively. As shown in Table 1 , the physical and chemical properties of soils in EM were greatly altered during the spatial expansion, which might influence the variation of V levels in soils. Similar results were reported by Ehrenfeld (2003) and Chacón et al. (2009) who reported that the alterations of plant species, community structure and ecological traits during alien species invasion significantly affected the physical and chemical properties of soils. Compared with PA or CM communities, both PA' and CM' in ecotone showed higher densities but the former occupied the higher spaces while the latter occupied the lower spaces (Fig. 5b). Just for this reason, the special space combination between $\mathrm{PA}^{\prime}$ and $\mathrm{CM}^{\prime}$ in EM might be more favorable for intercepting the suspended particulate matter in tide. Compared with PAM and CMM, the fine particles (clay and silt) in topsoil of EM increased $13.85 \%$ and $29.10 \%$, respectively (Table 1).

Simultaneously, considerable V element might be imported into ecotone, resulting in the higher V levels in soils of EM. As shown in Fig. 5 , the ecological traits of plants were also greatly altered during the spatial expansion, which might affect the variation of $\mathrm{V}$ levels in soils. Previous studies have reported that there were great differences in $\mathrm{V}$ absorption and accumulation among vegetations (Nawaz et al., 2018; Li et al., 2020a). Compared with PA or CM communities, both PA' and CM' in ecotone showed lower belowground and aboveground biomasses (Fig. $5 \mathrm{a}$ ), indicating that the absorption amounts of $\mathrm{V}$ by the two plants might be not very high and this, to some extent, could explain the higher $\mathrm{V}$ levels in EM soil.

In order to better visualize the possible environmental gradients determining the temporal variation of $V$ contents in soils of different marshes, the principal component analysis (PCA) was conducted (Fig. 6). In PAM, two principle components explained $92.98 \%$ of the variance. Principal component 1 (PC1), which explained $87.19 \%$ of the total variance, represented the gradient variations of plant height and aboveground biomass. Principal component 2 (PC2), which explained $5.79 \%$ of the total variance, showed the gradient variations of plant density, soil temperature and SOM. Further analyses indicated that the V levels showed strong correlation with PC2. By comparison, $84.73 \%$ of the total variance of environmental variables in EM was explained by two principle components (PC1 and PC2). PC1 represented the gradient variation of plant height and aboveground biomass, whereas PC2 showed the gradient variation of plant density and belowground biomass. Generally, the V levels showed close correlation with PC2. For CMM, 59.38\% and $13.95 \%$ of the total variance of environmental variables were explained by PC1 and PC2, respectively. PC1 represented the gradient variations of plant height, aboveground biomass and soil $\mathrm{pH}$, while PC2 showed the gradient variations of plant density and belowground biomass. As a whole, the $\mathrm{V}$ levels showed strong correlation with PC1. The above analyses indicated that the temporal variation of $\mathrm{V}$ levels in soils of EM, to a great extent, rested with the alterations of $\mathrm{pH}, \mathrm{SOM}$ and plant ecological traits during the spatial expansion between $\mathrm{PA}$ and $\mathrm{CM}$.

\subsection{Accumulation and transference of $\mathrm{V}$ in marsh plants}


This paper implied that the $\mathrm{V}$ contents in $\mathrm{PA}, \mathrm{PA}^{\prime}, \mathrm{CM}^{\prime}$ and $\mathrm{CM}$ differed among tissues, and, over all sampling seasons, the values in roots were significantly higher than those in other tissues (Fig. 3). Previous studies have indicated that, as V existed in growing medium, bioaccumulation was a key adaptive strategy for most plants (Saco et al., 2013; Hou et al., 2014). The bioaccumulation for $V$ generally occurred in roots, which was $2 \sim 1000$ folds of aboveground parts (Aihemaiti et al., 2020). Moreover, the $V$ in roots could form stable compound with calcium through the chelating and complexating the polar compound in cytoderm, which retarded the transference of soluble vanadium ion and reduced the $V$ bioaccumulation in aboveground parts (Kaplan et al., 1990). In this paper, the $\mathrm{R} / \mathrm{S}$ and $\mathrm{R} / \mathrm{L}$ ratios in $\mathrm{PA}, \mathrm{PA}$ ', $C M$ ' or $\mathrm{CM}$ were larger than 1 (Table 2), implying that the $\mathrm{V}$ contents in roots of the four plants were significantly higher than those in aboveground parts. This conclusion could be verified by the higher [BCF] in roots of different plants over all sampling seasons (Table 3). Besides, the S/L ratios in marsh plants were less than 1 (Table 2), indicating that the limited $\mathrm{V}$ nutrient transferred from roots to aboveground parts might be preferentially allocated to leaves and this was favorable for the biosynthesis of chlorophyll and the metabolism of carbohydrates in photosynthesis process (Nawaz et al., 2018). It was noting that, over all sampling seasons, the $V$ contents in standing litters were much higher that those in stems and leaves (Fig. 3), which might be dependent on the nutrients (including V) absorbed by plants and the nutrients retained in standing litters (Chen and Sun, 2020b). As mentioned above, the $\mathrm{V}$ in living bodies could form stable compound with calcium in cytoderm, which indicated that, as plant withered, the $V$ in these compounds could be stranded in standing litters in large numbers due to their poor mobility.

This paper showed that the $V$ contents in tissues differed among species. Over all sampling seasons, the $V$ levels in tissues of PA' were generally higher than those of PA and, similarly, the values in organs of CM' were much higher than those of CM (Fig. 3). The probable reason was related to the alteration of plant ecological traits and the competitive absorption for nutrients (including $\mathrm{V}$ ) by different plants during the spatial expansion. Compared to the pure community (PA or CM), the aboveground and belowground biomasses of PA' (or CM') significantly decreased (Fig. 5a), indicating that both the living spaces of PA' and CM' in ecotone were squeezed severely and their competitiveness for nutrient might be intense. Previous studies have found that, in habitat with limited nutrient, the competition advantage of plants generally rested with their conserved utilization for limited resources (Sardans and Peñuelas, 2014; Wang et al., 2018). It was reported that the spatial expansion of PA and CM in the Min River estuary was bi-directional (He et al., 2018) and the competitions between them rested with their ecological adaptation strategies ( $\mathrm{Li}$ et al., 2020a). In this paper, the $\mathrm{V}$ contents and the [BCF] in tissues of CM' were generally higher than those of PA' over all sampling seasons (Fig. 3, Table 3), which indicated that the PA' and $\mathrm{CM}^{\prime}$ in ecotone were very likely adopt different strategies for $\mathrm{V}$ absorption and utilization to maintain their competitiveness. Compared to PA, the density of PA' increased but its height, R/S and R/L ratios decreased greatly (Fig. 5, Table 2), implying that the $P$. australis might compete primarily by increasing the number of tillering and transferring the $V$ accumulated in roots to the photosynthetic organ (leaf) preferentially. However, compared with $\mathrm{CM}$, the density of CM' decreased but its height, R/S and R/L ratios generally increased (Fig. 5, Table 2), indicating that the $C$. malaccensis might resist the spatial expansion of $P$. australis by increasing the bioaccumulation of $\mathrm{V}$ in roots, decreasing the number of tillering and expanding the space of aboveground parts.

This paper indicated that the $V$ levels in tissues of PA, PA', CM' and CM differed among seasons, which could be better interpreted by the differences in growth rhythm and ecological traits among plants. In this study, the V contents in roots and leaves of PA (or PA') during spring were the highest, while those in summer and autumn were much lower (Fig. 3), implying that, compared to the vigorous growth stage, the roots of PA (or PA') at initial growth stage showed higher V bioaccumulation and higher transference from roots to leaves. By comparison, the $\mathrm{V}$ levels in roots and stems of $\mathrm{CM}$ (or CM') achieved the higher values in winter (Fig. 3). Previous studies have reported that the aboveground parts of PA (or PA') almost withered in winter, while those of CM (or CM') were not dead and, particularly, stem was the main body of aboveground parts (>94\%) (Wu et al., 2020; Li et al., 2020a). Thus, in order to keep alive and enhance the stress resistance for the lower temperatures in winter, the $V$ accumulated in roots of $\mathrm{CM}$ (or $\mathrm{CM}^{\prime}$ ) might be greatly transferred to stems. This paper also indicated that, over all sampling seasons, both the $V$ stocks in roots of PA' and CM' were much higher, but the values in stems and leaves of the former were generally higher than those of the latter (Table 4). As mentioned above, the two plants might adopt different strategies for $\mathrm{V}$ absorption and utilization during the spatial expansion. Compared to $\mathrm{CM}^{\prime}$, the PA' in ecotone might preferentially transfer the $\mathrm{V}$ in roots to the aboveground parts to maintain its competitiveness, which resulted in the higher $\mathrm{V}$ stock in its aboveground parts.

\section{Declarations}

\section{Acknowledgement}

This study was financially supported by the National Nature Science Foundation of China (No. 41971128), the Innovation Project of South China Sea Ecology and Environmental Engineering, Chinese Academy of Sciences (ISEE2019ZRO), and the Award Program for 
Min River Scholar in Fujian Province (No. Min[2015]31).

Funding: This study was financially supported by the National Nature Science Foundation of China (No. 41971128), the Innovation Project of South China Sea Ecology and Environmental Engineering, Chinese Academy of Sciences (ISEE2019ZR0), and the Award Program for Min River Scholar in Fujian Province (No. Min[2015]31).

Ethical Approval and consent to participate: Not applicable.

Conflicts of interest: The authors declare that they have no competing interests.

Consent for publication: Not applicable.

Availability of data and materials: All data produced from this study are provided in this manuscript.

Code availability: Not applicable.

Authors' contributions: Shaohui Yao analyzed the experimental data and was a major contributor in writing the manuscript. Zhigao Sun revised this paper and interpreted the key mechanism of vanadium bioaccumulation in marsh plants. Yajin Li and Xiao Li participated in sample analysis. All authors read and approved the final manuscript.

\section{References}

1. Aihemaiti A, Gao YC, Meng Y, Chen XJ, Liu JW, Xiang HL, Xu YW, Jiang JG (2020) Review of plant-vanadium physiological interactions, bioaccumulation, and bioremediation of vanadium-contaminated sites. Sci Total Environ 712:135637

2. Boyer A, Ning P, Killey D, Klukas M, Rowan D, Simpson AJ, Passeport E (2018) Strontium adsorption and desorption in wetlands: Role of organic matter functional groups and environmental implications. Water Res 133:27-36

3. Chacón N, Herrera I, Flores S, González JA, Nassar JM (2009) Chemical, physical, and biochemical soil properties and plant roots as affected by native and exotic plants in Neotropical arid zones. Biol Fert Soils 45(3):321-328

4. Chen BB, Sun ZG (2020a) Potential effects of episodic deposition on nutrients an heavy metals in decomposing litters of Suaeda glauca in salt marsh of the Yellow River estuary, China. Chin Geogra Sci 30(3):466-482

5. Chen BB, Sun ZG (2020b) Effects of nitrogen enrichment on variations of sulfur in plant-soil system of Suaeda salsa in coastal marsh of the Yellow River estuary, China. Ecollndic 109:105797

6. Chen Q, Ma KM (2017) Effects of Spartina alterniflora invasion on enrichment of sedimental heavy metals in a mangrove wetland and the underlying mechanisms. Chin J Plant Ecol 41(4):409-417

7. Chen XX, Chen SY, Zeng CS, Wang WQ (2018) Effects of crabs on soil carbon, nitrogen, phosphorus concentration and ecological stoichiometry in Minjiang River estuarine wetlands. Acta Sci Circum 38(3):1179-1188

8. Chen ZJ, Chenm CX, Liu YQ, Lin ZS (1992) Background values and distribution of elements in soils of Fujian Province. Environ Monit Chin 8(3):107-110

9. Dahmani-Muller H, Van OF, Gélie B, Balabane M (2000) Strategies of heavy metal uptake by three plant species growing near a metal smelter. Environ Pollut 109(2):231-238

10. Dai ZZ (2004) Analysis of hydrologic features in the Fuzhou district. Hydraul Sci Technol 3:9-11

11. Du LG, Rinklebe J, Vandecasteele B, Meers E, Tack FM (2009) Trace metal behaviour in estuarine and riverine floodplain soils and sediment: A review. Sci Total Environ 407(13):3972-3985

12. Duman F, Cicek M, Sezen G (2007) Seasonal changes of metal accumulation and distribution in common club rush (Schoenoplectus lacustris) and common reed (Phragmites australis). Ecotoxicology 16:457-463

13. Ehrenfeld JG (2003) Effects of exotic plant invasions on soil nutrient cycling processes. Ecosystems 6(6):503-523

14. Ewanchuk PJ, Bertness MD (2004) Structure and organization of a northern New England salt marsh plant community. J Ecol 92(1):72-85

15. He T, Sun ZG, Hu XY, Chen BB, Wang H, Wang J (2020) Effects of Spartina alterniflora invasion on spatial and temporal variations of total sulfur and inorganic sulfur fractions in sediments of salt marsh in the Min River estuary, southeast China. Ecollndic 113:106253

Page $8 / 20$ 
16. He T, Sun ZG, Li JB, Gao H, Fan AL (2018) Variations in total sulfur content in plant-soil systems of Phragmites australis and Cyperus malaccensis in the process of their spatial expansion in the Min River estuary. Acta Ecol Sin 38(5):1607-1618

17. Herbert ER, Schubauer-Berigan J, Craft CB (2018) Differential effects of chronic and acute simulated seawater intrusion on tidal freshwater marsh carbon cycling. Biogeochemistry138, 137-154

18. Hou M, Lu C, Wei KX (2014) Accumulation and speciation of vanadium in Lycium seedling. Biol Trace Elem Res 159:373-378

19. Huang CY (2003) Soil Science. China Agriculture Press, Beijing

20. Jiao XD, Teng YG (2008) Techniques on soil remediation and disposal of vanadium pollution. Chin J Soil Sci 39(2):448-452

21. Kaplan DI, Sajwan KS, Adriano DC (1990) Phytoavailability and toxicity of beryllium and vanadium. Water Air Soil Poll 53(3/4):203-212

22. Keshta AE, Shaltout KH, Baldwin AH, SharafEI-Din AA (2020) Sediment clays are trapping heavy metals in urban lakes: An indicator for severe industrial and agricultural influence on coastal wetlands at the Mediterranean coast of Egypt. Mar Pollut Bull 151:110816

23. Korol AR, Changwoo, Ahn, Noe GB (2016) Richness, biomass, and nutrient content of a wetland macrophyte community affect soil nitrogen cycling in a diversity-ecosystem functioning experiment. Ecol Eng 95:252-265

24. Li YJ, Sun ZG, Li X, Hu XY, Chen BB, Wang H, Zhang PF (2020a) Effects of spatial expansion between Phragmites australis and Cyperus malaccensis on bioaccumulation of vanadium in plants of different marshes in the Min River estuary. Acta Sci Circum 40(12):4559-4569

25. Li X, Sun ZG, Tian LP, He T, Li J, Wang J, Wang H, Chen BB (2020b) Effects of spatial expansion between Phragmites australis and Cyperus malaccensis on variations of arsenic and heavy metals in decomposing litters in a typical subtropical estuary (Min River), China. Chemosphere 240, 124965

26. Li X, Sun ZG, Li YJ, Chen BB, Hu XY, He T, Zhang PF (2020c) Adsorption-desorption characteristic of micro-elements in soils of salt marshes in the Min River estuary and its response to pH variations. Acta Sci Circum 40(5):1807-1820

27. Li YS, Redmann RE (1992) Nitrogen budget of Agropyron dasystachyum in Canadian mixed prairie. Am Midl Nat 128(1):61-71

28. Liu JQ, Zeng CS, Chen N (2006) Research of Minjiang River estuary wetland. Science Press, Beijing

29. Lu YZ, Yan BX (2010) Competitive adsorption of heavy metals on Songhua River sediments and effect of pH. Res Environ Sci 23(1):20-25

30. Moran SB, Yeats PA, Balls. PW (1996) On the role of colloids in trace metal solid-solution partitioning in continental shelf waters: a comparison of model results and field data. Cont Shelf Res 16:397-408

31. Nawaz MA, Jiao YY, Chen C, Shireen F, Zheng ZH, Imtiaz M, Bie ZL, Huang Y (2018) Melatonin pretreatment improves vanadium stress tolerance of watermelon seedlings by reducing vanadium concentration in the leaves and regulating melatonin biosynthesis and antioxidant-related gene expression. J Plant Physiol 220(1):115-127

32. Nie LS (2011) Elemental abundances and distribution in China, Europe and North America continents. Ph.D degree dissertation, China University of Geosciences (Beijing), Beijing

33. Pan XL (2001) Cause analysis and prevention measures for acid rain in Fujian provinces. Hydrology 21(1):47-49

34. Saco D, Martín S, San Jose P (2013) Vanadium distribution in roots and leaves of Phaseolus vulgaris: morphological and ultrastructural effects. Biol Plantarum 57(1):128-132

35. Sardans J, Peñuelas J (2014) Climate and taxonomy underlie different elemental concentrations and stoichiometries of forest species: the optimum "biogeochemical niche". Plant Ecol 215(4):441-455

36. Simas T, Nunes JP, Ferreira JG (2001) Effects of global climate change on coastal salt marshes. Ecol Model 139:1-15

37. Sun ZG, Li JB, He T, Ren P, Zhu H, Gao H, Tian LP, Hu XY (2017) Spatial variation and toxicity assessment for heavy metals in sediments of intertidal zone in a typical subtropical estuary (Min River) of China. Environ. Sci Pollut Res 24:23080-23095

38. Tong C, Zhang LH, Wang WQ, Gauci V, Marrs R, Liu BG, Jia R, Zeng CS (2011) Contrasting nutrient stocks and litter decomposition in stands of native and invasive species in a sub-tropical estuarine marsh. Environ Res 111(7):909-916

39. Vilà M, Espinar JL, Hejda M, Hulme PE, Jarošík V, Maron JL, Pergl J, Schaffner U, Sun Y, Pyšek P (2011) Ecological impacts of invasive alien plants: a meta-analysis of their effects on species, communities and ecosystems. Ecol Lett 14(7):702-708

40. Wan SZ, Yang GS, Mao R (2020) Responses of leaf nitrogen and phosphorus allocation patterns to nutrient additions in a temperate freshwater wetland. Ecol Indic 110:105949

Page 9/20 
41. Wang H, Sun ZG, Li JB, He T, Gao H, Wang J, Lin PZ, Wu XT (2018) Spatial variations of soil carbon and nitrogen contents in Phragmites australis and Cyperus malaccensis marsh in the Minjiang River estuary. Chin J Ecol 37(4):1102-1110

42. Wang J, Sun ZG, Li JB, He T, Fan AL, Gao H, Wang H (2018) Distributions of soil organic carbon and nitrogen in marshes of the Minjiang River estuary in the end of July of 2015 under different flooding conditions. Wetland Sci 16(4):559-567

43. Wang JF, Liu Z (1994) Vanadium distribution and its affecting factors in soils of China. Acta Pedol Sin 31(1):61-67

44. Wang Y, Wei FS (1995) Environmental Elemental Chemistry in Soil. China Environmental Science Press, Beijing

45. Wu XT, Sun ZG, Wang H, Chen BB, Hu XY (2020) Spatial and temporal variations of sulfur in plant-soil systems of Phragmites australis and Cyperus malaccensis marshes in a typical subtropical estuary (Min River), China. Wetlands 40(5), 1283-1293

46. Zhang PF, Sun ZG, Chen BB, Hu XY, Li X, He T, Mao L, Zhang WT (2020) Effects of spatial expansion of Phragmites australis and Cyperus malaccensis on distributions and stocks of phosphorus in marshes in the Minjiang River estuary, China. Chin J Appl Ecol 31(12):4258-4266

47. Zhang WL, Zeng CS, Tong C, Zhang ZC, Huang JF (2011) Analysis of the expanding process of the Spartina alterniflora salt marsh in Shanyutan wetland, Minjiang River estuary by remote sensing. Procedia Environ Sci 10(C):2472-2477

48. Zhang YH, Ding WX, Luo JF, Donnison A (2010) Changes in soil organic carbon dynamics in an Eastern Chinese coastal wetland following invasion by a $\mathrm{C}_{4}$ plant Spartina alterniflora. Soil Biol Biochem 42(10):1712-1720

49. Zheng CH, Zeng CS, Chen ZQ (2006) A study on the changes of landscape pattern of estuary wetlands of the Minjiang River. Wetland Sci 4:29-34

50. Zhu H, Sun ZG, Yi HP, Ren P (2016) Spatial distribution characteristics of soil vanadium and cobalt contents in different types of wetlands in the Yellow River estuary. J Soil Water Conserv 30(1):315-320

\section{Tables}

Table 1

Physical and chemical properties of topsoil in different marshes of the experimental plots over all sampling seasons

\begin{tabular}{|c|c|c|c|c|c|c|c|c|c|}
\hline \multirow[t]{2}{*}{ Marshes } & \multicolumn{3}{|c|}{ Grain composition (\%) } & \multirow{2}{*}{$\begin{array}{l}\text { Soil bulk } \\
\text { density } \\
\left(\mathrm{g} \cdot \mathrm{cm}^{-3}\right)\end{array}$} & \multirow{2}{*}{$\begin{array}{l}\text { Soil } \\
\text { moisture } \\
(\%)\end{array}$} & \multirow{2}{*}{$\begin{array}{l}\text { Electrical } \\
\text { conductivity (EC) } \\
\left(\mathrm{mS} \cdot \mathrm{cm}^{-1}\right)\end{array}$} & \multirow[t]{2}{*}{$\mathrm{pH}$} & \multirow{2}{*}{$\begin{array}{l}\text { Soil organic } \\
\text { matter } \\
(\mathrm{SOM})(\%)\end{array}$} & \multirow{2}{*}{$\begin{array}{l}\text { Soil } \\
\text { temperature } \\
\left({ }^{\circ} \mathrm{C}\right)\end{array}$} \\
\hline & Clay & Silt & Sand & & & & & & \\
\hline PAM & $\begin{array}{l}16.27 \pm \\
0.52 a\end{array}$ & $\begin{array}{l}54.14 \pm \\
0.22 a\end{array}$ & $\begin{array}{l}29.59 \pm \\
0.73 a\end{array}$ & $\begin{array}{l}0.91 \pm \\
0.02 \mathrm{a}\end{array}$ & $\begin{array}{l}46.81 \pm \\
4.68 a\end{array}$ & $1.61 \pm 0.19 a$ & $\begin{array}{l}5.86 \pm \\
0.79 a\end{array}$ & $\begin{array}{l}5.01 \pm \\
0.96 a\end{array}$ & $\begin{array}{l}22.81 \pm \\
6.78 a\end{array}$ \\
\hline EM & $\begin{array}{l}15.73 \pm \\
0.09 b\end{array}$ & $\begin{array}{l}64.43 \pm \\
0.65 b\end{array}$ & $\begin{array}{l}19.84 \pm \\
0.74 b\end{array}$ & $\begin{array}{l}0.95 \pm \\
0.02 \mathrm{a}\end{array}$ & $\begin{array}{l}48.33 \pm \\
2.95 a\end{array}$ & $1.79 \pm 0.34 a$ & $\begin{array}{l}6.38 \pm \\
0.98 a\end{array}$ & $\begin{array}{l}5.06 \pm \\
1.30 \mathrm{a}\end{array}$ & $\begin{array}{l}22.99 \pm \\
6.84 a\end{array}$ \\
\hline CMM & $\begin{array}{l}9.76 \pm \\
0.78 c\end{array}$ & $\begin{array}{l}52.33 \pm \\
2.22 c\end{array}$ & $\begin{array}{l}37.91 \pm \\
2.98 c\end{array}$ & $\begin{array}{l}0.89 \pm \\
0.05 a\end{array}$ & $\begin{array}{l}48.51 \pm \\
3.78 a\end{array}$ & $1.88 \pm 0.30 a$ & $\begin{array}{l}6.45 \pm \\
0.82 a\end{array}$ & $\begin{array}{l}4.69 \pm \\
0.91 a\end{array}$ & $\begin{array}{l}23.38 \pm \\
6.79 a\end{array}$ \\
\hline
\end{tabular}


Table 2

Vanadium concentration quotients for roots/stems (R/S), roots/leaves (R/L) and stems/leaves (S/L) in different marsh plants over all sampling seasons

\begin{tabular}{|c|c|c|c|c|c|}
\hline Vegetations & Ratios & Spring & Summer & Autumn & Winter \\
\hline \multirow[t]{3}{*}{ PA } & $\mathrm{R} / \mathrm{S}$ & $18.70 \pm 5.27$ & $25.74 \pm 9.35$ & $8.24 \pm 0.27$ & $6.83 \pm 5.91$ \\
\hline & $R / L$ & $5.93 \pm 0.12$ & $11.92 \pm 5.61$ & $3.90 \pm 0.13$ & $4.94 \pm 2.33$ \\
\hline & $S / L$ & $0.33 \pm 0.10$ & $0.45 \pm 0.05$ & $0.47 \pm .00$ & $0.92 \pm 0.46$ \\
\hline \multirow[t]{3}{*}{$\mathrm{PA}^{\prime}$} & $R / S$ & $16.78 \pm 5.47$ & $12.96 \pm 1.47$ & $1.25 \pm 0.59$ & $6.61 \pm 0.29$ \\
\hline & $R / L$ & $6.38 \pm 1.69$ & $5.75 \pm 1.49$ & $3.13 \pm 3.58$ & $3.83 \pm 1.07$ \\
\hline & $S / L$ & $0.42 \pm 0.24$ & $0.44 \pm 0.07$ & $2.05 \pm 1.89$ & $0.58 \pm 0.14$ \\
\hline \multirow[t]{3}{*}{$\mathrm{CM}^{\prime}$} & $R / S$ & $6.34 \pm 1.91$ & $25.79 \pm 17.67$ & $10.99 \pm 2.02$ & $14.09 \pm 1.98$ \\
\hline & $R / L$ & $5.86 \pm 0.40$ & $8.22 \pm 4.26$ & $1.93 \pm 0.54$ & NA \\
\hline & S/L & $0.96 \pm 0.23$ & $0.34 \pm 0.07$ & $0.18 \pm 0.08$ & NA \\
\hline \multirow[t]{3}{*}{$\mathrm{CM}$} & $R / S$ & $4.74 \pm 2.54$ & $9.26 \pm 3.68$ & $10.49 \pm .39$ & $14.00 \pm 2.73$ \\
\hline & $R / L$ & $3.57 \pm 2.10$ & $5.15 \pm 2.49$ & $4.72 \pm 3.86$ & NA \\
\hline & $S / L$ & $0.74 \pm 0.05$ & $0.55 \pm 0.05$ & $0.42 \pm 0.27$ & NA \\
\hline
\end{tabular}

Notes: NA, not available. PA, Phragmites australis; CM, Cyperus malaccensis; PA', Phragmites australis in ecotonal marsh; and CM', Cyperus malaccensis in ecotonal marsh. 
Table 3

Bioconcentration factors (BCF) of vanadium in organs of different marsh plants over all sampling seasons

\begin{tabular}{|c|c|c|c|c|c|}
\hline Tissues & Vegetations & Spring & Summer & Autumn & Winter \\
\hline \multirow[t]{4}{*}{ Roots } & PA & $0.10 \pm 0.02$ & $0.06 \pm 0.02$ & $0.06 \pm 0.01$ & $0.07 \pm 0.04$ \\
\hline & $\mathrm{PA}^{\prime}$ & $0.19 \pm 0.00$ & $0.06 \pm 0.03$ & $0.04 \pm 0.05$ & $0.07 \pm 0.01$ \\
\hline & $\mathrm{CM}^{\prime}$ & $0.12 \pm 0.01$ & $0.12 \pm 0.03$ & $0.10 \pm 0.03$ & $0.15 \pm 0.01$ \\
\hline & $\mathrm{CM}$ & $0.08 \pm 0.06$ & $0.10 \pm 0.04$ & $0.15 \pm 0.07$ & $0.17 \pm 0.08$ \\
\hline \multirow[t]{4}{*}{ Stems } & PA & $0.01 \pm 0.00$ & $0.00 \pm 0.00$ & $0.01 \pm 0.00$ & $0.01 \pm 0.01$ \\
\hline & $\mathrm{PA}^{\prime}$ & $0.01 \pm 0.00$ & $0.00 \pm 0.00$ & $0.03 \pm 0.02$ & $0.01 \pm 0.00$ \\
\hline & $\mathrm{CM}^{\prime}$ & $0.02 \pm 0.01$ & $0.01 \pm 0.00$ & $0.01 \pm 0.00$ & $0.01 \pm 0.00$ \\
\hline & $\mathrm{CM}$ & $0.02 \pm 0.00$ & $0.01 \pm 0.00$ & $0.01 \pm 0.00$ & $0.01 \pm 0.00$ \\
\hline \multirow[t]{4}{*}{ Leaves } & PA & $0.02 \pm 0.00$ & $0.01 \pm 0.00$ & $0.01 \pm 0.00$ & $0.01 \pm 0.00$ \\
\hline & $\mathrm{PA}^{\prime}$ & $0.03 \pm 0.01$ & $0.01 \pm 0.00$ & $0.01 \pm 0.00$ & $0.02 \pm 0.01$ \\
\hline & $\mathrm{CM}^{\prime}$ & $0.02 \pm 0.00$ & $0.02 \pm 0.00$ & $0.06 \pm 0.03$ & $0.00 \pm 0.00$ \\
\hline & $\mathrm{CM}$ & $0.02 \pm 0.00$ & $0.02 \pm 0.00$ & $0.04 \pm 0.02$ & $0.00 \pm 0.00$ \\
\hline \multirow[t]{4}{*}{ Standing litters } & PA & $0.04 \pm 0.01$ & $0.02 \pm 0.01$ & $0.03 \pm 0.01$ & $0.02 \pm 0.01$ \\
\hline & $\mathrm{PA}^{\prime}$ & $0.08 \pm 0.01$ & $0.03 \pm 0.00$ & $0.03 \pm 0.00$ & $0.04 \pm 0.01$ \\
\hline & $\mathrm{CM}^{\prime}$ & $0.10 \pm 0.03$ & $0.04 \pm 0.01$ & $0.05 \pm 0.02$ & $0.08 \pm 0.04$ \\
\hline & $\mathrm{CM}$ & $0.12 \pm 0.01$ & $0.06 \pm 0.01$ & $0.05 \pm 0.01$ & $0.08 \pm 0.01$ \\
\hline
\end{tabular}

Notes: PA, Phragmites australis; CM, Cyperus malaccensis; PA', Phragmites australis in ecotonal marsh; and CM', Cyperus malaccensis in ecotonal marsh. 
Table 4

Stocks and allocations of vanadium in plant-soil systems of Phragmites australis, Cyperus malaccensis and ecotonal marshes over all sampling seasons

\begin{tabular}{|c|c|c|c|c|c|c|c|c|c|c|}
\hline \multirow[t]{2}{*}{ Marshes } & \multirow[t]{2}{*}{ Vegetations } & \multirow[t]{2}{*}{ Seasons } & \multirow[t]{2}{*}{ Items } & \multirow[t]{2}{*}{ Roots } & \multicolumn{2}{|c|}{$\begin{array}{l}\text { Aboveground } \\
\text { parts }\end{array}$} & \multirow[t]{2}{*}{$\begin{array}{l}\text { Standing } \\
\text { litters }\end{array}$} & \multirow[t]{2}{*}{$\begin{array}{l}\text { Plant } \\
\text { subsystems }\end{array}$} & \multirow{2}{*}{$\begin{array}{l}\text { Soils } \\
(0-60 \\
\mathrm{cm})\end{array}$} & \multirow[t]{2}{*}{$\begin{array}{l}\text { Plant-soil } \\
\text { systems }\end{array}$} \\
\hline & & & & & Stems & Leaves & & & & \\
\hline \multirow[t]{8}{*}{ PAM } & \multirow[t]{8}{*}{ PA } & \multirow[t]{2}{*}{ Spring } & $\begin{array}{l}\text { Stock } \\
\left(\mathrm{mg} \cdot \mathrm{m}^{-}\right. \\
\left.{ }^{2}\right)\end{array}$ & $\begin{array}{l}14.61 \\
\pm 5.40\end{array}$ & $\begin{array}{l}0.01 \\
\pm 0.00\end{array}$ & $\begin{array}{l}0.02 \pm \\
0.00\end{array}$ & $\begin{array}{l}3.02 \pm \\
1.12\end{array}$ & 17.66 & 55128.19 & 55145.85 \\
\hline & & & $\begin{array}{l}\text { Percent } \\
(\%)\end{array}$ & $\begin{array}{l}82.73 \\
a\end{array}$ & $0.07^{\mathrm{a}}$ & $0.12^{a}$ & $17.08^{a}$ & $0.03^{b}$ & $99.97^{b}$ & 100 \\
\hline & & \multirow[t]{2}{*}{ Summer } & $\begin{array}{l}\text { Stock } \\
\left(\mathrm{mg} \cdot \mathrm{m}^{-}\right. \\
\left.{ }^{2}\right)\end{array}$ & $\begin{array}{l}10.24 \\
\pm 0.74\end{array}$ & $\begin{array}{l}0.19 \\
\pm 0.02\end{array}$ & $\begin{array}{l}0.19 \pm \\
0.00\end{array}$ & $\begin{array}{l}0.60 \pm \\
0.17\end{array}$ & 11.22 & 53090.48 & 53101.7 \\
\hline & & & $\begin{array}{l}\text { Percent } \\
(\%)\end{array}$ & $\begin{array}{l}91.22 \\
\mathrm{a}\end{array}$ & $1.70^{a}$ & $1.73^{a}$ & $5.35^{a}$ & $0.02^{b}$ & $99.98^{b}$ & 100 \\
\hline & & \multirow[t]{2}{*}{ Autumn } & $\begin{array}{l}\text { Stock } \\
\left(\mathrm{mg} \cdot \mathrm{m}^{-}\right. \\
\left.{ }^{2}\right)\end{array}$ & $\begin{array}{l}8.29 \\
\pm 2.19\end{array}$ & $\begin{array}{l}0.55 \\
\pm 0.17\end{array}$ & $\begin{array}{l}0.23 \pm \\
0.04\end{array}$ & $\begin{array}{l}1.55 \pm \\
0.22\end{array}$ & 10.62 & 50563.73 & 50574.35 \\
\hline & & & $\begin{array}{l}\text { Percent } \\
(\%)\end{array}$ & $\begin{array}{l}78.06 \\
a\end{array}$ & $5.19^{a}$ & $2.12^{a}$ & $14.62^{a}$ & $0.02^{b}$ & $99.98^{b}$ & 400 \\
\hline & & \multirow[t]{2}{*}{ Winter } & $\begin{array}{l}\text { Stock } \\
\left(\mathrm{mg} \cdot \mathrm{m}^{-}\right. \\
\left.{ }^{2}\right)\end{array}$ & $\begin{array}{l}8.00 \\
\pm 0.80\end{array}$ & $\begin{array}{l}1.17 \\
\pm 1.17\end{array}$ & $\begin{array}{l}0.03 \pm \\
0.01\end{array}$ & $\begin{array}{l}1.27 \pm \\
0.20\end{array}$ & 10.47 & 62339.20 & 62349.67 \\
\hline & & & $\begin{array}{l}\text { Percent } \\
(\%)\end{array}$ & $\begin{array}{l}76.41 \\
a\end{array}$ & $\begin{array}{l}11.18 \\
a\end{array}$ & $0.32^{\mathrm{a}}$ & $12.08^{a}$ & $0.02^{b}$ & $99.98^{b}$ & 100 \\
\hline \multirow[t]{7}{*}{ EM } & \multirow[t]{7}{*}{$\mathrm{PA}^{\prime}$} & \multirow[t]{2}{*}{ Spring } & $\begin{array}{l}\text { Stock } \\
\left(\mathrm{mg} \cdot \mathrm{m}^{-}\right. \\
2)\end{array}$ & $\begin{array}{l}13.29 \\
\pm 2.68\end{array}$ & $\begin{array}{l}0.06 \\
\pm 0.02\end{array}$ & $\begin{array}{l}0.07 \pm \\
0.01\end{array}$ & $\begin{array}{l}2.09 \pm \\
1.05\end{array}$ & 15.51 & 58338.40 & 58353.91 \\
\hline & & & $\begin{array}{l}\text { Percent } \\
(\%)\end{array}$ & $\begin{array}{l}85.69 \\
a\end{array}$ & $0.40^{a}$ & $0.45^{\mathrm{a}}$ & $13.46^{a}$ & $0.03^{b}$ & $99.97^{b}$ & 100 \\
\hline & & \multirow[t]{2}{*}{ Summer } & $\begin{array}{l}\text { Stock } \\
\left(\mathrm{mg} \cdot \mathrm{m}^{-}\right. \\
\left.{ }^{2}\right)\end{array}$ & $\begin{array}{l}8.05 \\
\pm 4.96\end{array}$ & $\begin{array}{l}0.11 \\
\pm 0.04\end{array}$ & $\begin{array}{l}0.19 \pm \\
0.02\end{array}$ & $\begin{array}{l}1.10 \pm \\
0.18\end{array}$ & 9.44 & 56081.76 & 56091.2 \\
\hline & & & $\begin{array}{l}\text { Percent } \\
(\%)\end{array}$ & $\begin{array}{l}85.19 \\
a\end{array}$ & $1.14^{\mathrm{a}}$ & $2.00^{a}$ & $11.67^{a}$ & $0.02^{b}$ & $99.98^{b}$ & 100 \\
\hline & & \multirow[t]{2}{*}{ Autumn } & $\begin{array}{l}\text { Stock } \\
\left(\mathrm{mg} \cdot \mathrm{m}^{-}\right. \\
\left.{ }^{2}\right)\end{array}$ & $\begin{array}{l}3.66 \\
\pm .76\end{array}$ & $\begin{array}{l}0.94 \\
\pm 0.55\end{array}$ & $\begin{array}{l}0.21 \pm \\
0.06\end{array}$ & $\begin{array}{l}1.39 \pm \\
0.78\end{array}$ & 6.20 & 56207.39 & 56213.59 \\
\hline & & & $\begin{array}{l}\text { Percent } \\
(\%)\end{array}$ & $\begin{array}{l}58.98 \\
a\end{array}$ & $\begin{array}{l}15.23 \\
a\end{array}$ & $3.40^{a}$ & 22.39 a & $0.01^{b}$ & 99.99 b & 100 \\
\hline & & Winter & $\begin{array}{l}\text { Stock } \\
\left(\mathrm{mg} \cdot \mathrm{m}^{-}\right. \\
\left.{ }^{2}\right)\end{array}$ & $\begin{array}{l}1.60 \\
\pm 0.28\end{array}$ & $\begin{array}{l}0.08 \\
\pm 0.01\end{array}$ & $\begin{array}{l}0.05 \pm \\
0.02\end{array}$ & $\begin{array}{l}1.85 \pm \\
0.91\end{array}$ & 3.58 & 63632.86 & 63636.44 \\
\hline
\end{tabular}

Notes: NA, not available. PAM, Phragmites australis marsh; EM, ecotonal marsh; and CMM, Cyperus malaccensis marsh. PA, Phragmites australis; CM, Cyperus malaccensis; PA', Phragmites australis in ecotonal marsh; and CM', Cyperus malaccensis in ecotonal marsh. ${ }^{a}$ Percent of plant subsystem; and ${ }^{b}$ percent of plant-soil system. 


\begin{tabular}{|c|c|c|c|c|c|c|c|c|c|c|}
\hline & & & $\begin{array}{l}\text { Percent } \\
(\%)\end{array}$ & $\begin{array}{l}44.76 \\
a\end{array}$ & $2.11^{\mathrm{a}}$ & $1.37^{a}$ & $51.76^{a}$ & $0.01^{b}$ & $99.99^{b}$ & 100 \\
\hline \multirow{8}{*}{\multicolumn{2}{|c|}{$\mathrm{CM}^{\prime}$}} & \multirow[t]{2}{*}{ Spring } & $\begin{array}{l}\text { Stock } \\
\left(\mathrm{mg} \cdot \mathrm{m}^{-}\right. \\
2)\end{array}$ & $\begin{array}{l}5.52 \\
\pm 0.69\end{array}$ & $\begin{array}{l}0.28 \\
\pm 0.16\end{array}$ & $\begin{array}{l}0.0037 \\
\pm 0.00\end{array}$ & $\begin{array}{l}1.41 \pm \\
0.84\end{array}$ & 7.21 & 58338.40 & 58345.61 \\
\hline & & & $\begin{array}{l}\text { Percent } \\
(\%)\end{array}$ & $\begin{array}{l}76.52 \\
a\end{array}$ & $3.88^{a}$ & $0.05^{a}$ & $19.55^{\mathrm{a}}$ & $0.01^{b}$ & $99.99^{b}$ & 100 \\
\hline & & \multirow[t]{2}{*}{ Summer } & $\begin{array}{l}\text { Stock } \\
\left(\mathrm{mg} \cdot \mathrm{m}^{-}\right. \\
\left.{ }_{2}\right)\end{array}$ & $\begin{array}{l}2.79 \\
\pm 1.35\end{array}$ & $\begin{array}{l}0.10 \\
\pm 0.08\end{array}$ & $\begin{array}{l}0.0031 \\
\pm \\
0.0010\end{array}$ & $\begin{array}{l}0.07 \pm \\
0.01\end{array}$ & 2.96 & 56081.76 & 56084.72 \\
\hline & & & $\begin{array}{l}\text { Percent } \\
(\%)\end{array}$ & $\begin{array}{l}94.16 \\
a\end{array}$ & $3.37^{a}$ & $0.10^{a}$ & $2.36^{a}$ & $0.01^{b}$ & $99.99^{b}$ & 100 \\
\hline & & \multirow[t]{2}{*}{ Autumn } & $\begin{array}{l}\text { Stock } \\
\left(\mathrm{mg} \cdot \mathrm{m}^{-}\right. \\
2)\end{array}$ & $\begin{array}{l}4.80 \\
\pm 2.53\end{array}$ & $\begin{array}{l}0.48 \\
\pm 0.09\end{array}$ & $\begin{array}{l}0.01 \pm \\
0.01\end{array}$ & $\begin{array}{l}0.16 \pm \\
0.00\end{array}$ & 5.45 & 56207.39 & 56212.84 \\
\hline & & & $\begin{array}{l}\text { Percent } \\
(\%)\end{array}$ & $\begin{array}{l}88.13 \\
a\end{array}$ & $8.78^{a}$ & $0.17^{a}$ & $2.92^{a}$ & $0.01^{b}$ & $99.99^{b}$ & 100 \\
\hline & & \multirow[t]{2}{*}{ Winter } & $\begin{array}{l}\text { Stock } \\
\left(\mathrm{mg} \cdot \mathrm{m}^{-}\right. \\
2)\end{array}$ & $\begin{array}{l}7.02 \\
\pm 3.72\end{array}$ & $\begin{array}{l}0.34 \\
\pm 0.10\end{array}$ & NA & $\begin{array}{l}1.17 \pm \\
0.86\end{array}$ & 8.53 & 63632.86 & 63641.39 \\
\hline & & & $\begin{array}{l}\text { Percent } \\
(\%)\end{array}$ & $\begin{array}{l}82.30 \\
a\end{array}$ & $4.01^{\mathrm{a}}$ & NA & $13.69^{a}$ & $0.01^{b}$ & $99.99^{b}$ & 100 \\
\hline \multirow[t]{8}{*}{ CMM } & \multirow[t]{8}{*}{$\mathrm{CM}$} & \multirow[t]{2}{*}{ Spring } & $\begin{array}{l}\text { Stock } \\
\left(\mathrm{mg} \cdot \mathrm{m}^{-}\right. \\
2)\end{array}$ & $\begin{array}{l}6.51 \\
\pm 4.53\end{array}$ & $\begin{array}{l}0.53 \\
\pm 0.07\end{array}$ & $\begin{array}{l}0.01 \pm \\
0.01\end{array}$ & $\begin{array}{l}4.31 \pm \\
1.62\end{array}$ & 11.36 & 57123.13 & 57134.49 \\
\hline & & & $\begin{array}{l}\text { Percent } \\
\text { (\%) }\end{array}$ & $\begin{array}{l}57.31 \\
a\end{array}$ & $4.67^{\mathrm{a}}$ & $0.09^{a}$ & $37.94^{\mathrm{a}}$ & $0.02^{b}$ & $99.98^{b}$ & 100 \\
\hline & & \multirow[t]{2}{*}{ Summer } & $\begin{array}{l}\text { Stock } \\
\left(\mathrm{mg} \cdot \mathrm{m}^{-}\right. \\
2)\end{array}$ & $\begin{array}{l}8.46 \\
\pm 4.26\end{array}$ & $\begin{array}{l}0.70 \\
\pm 0.27\end{array}$ & $\begin{array}{l}0.01 \pm \\
0.00\end{array}$ & $\begin{array}{l}1.29 \pm \\
0.62\end{array}$ & 10.46 & 50984.14 & 50994.6 \\
\hline & & & $\begin{array}{l}\text { Percent } \\
(\%)\end{array}$ & $\begin{array}{l}80.88 \\
a\end{array}$ & $6.69^{a}$ & $0.10^{a}$ & $12.33^{a}$ & $0.02^{b}$ & $99.98^{b}$ & 100 \\
\hline & & \multirow[t]{2}{*}{ Autumn } & $\begin{array}{l}\text { Stock } \\
\left(\mathrm{mg} \cdot \mathrm{m}^{-}\right. \\
\left.{ }^{2}\right)\end{array}$ & $\begin{array}{l}15.95 \\
\pm \\
11.67\end{array}$ & $\begin{array}{l}1.44 \\
\pm 0.79\end{array}$ & $\begin{array}{l}0.01 \pm \\
0.01\end{array}$ & $\begin{array}{l}0.92 \pm \\
0.41\end{array}$ & 18.32 & 53434.86 & 53453.18 \\
\hline & & & $\begin{array}{l}\text { Percent } \\
(\%)\end{array}$ & $\begin{array}{l}87.07 \\
a\end{array}$ & $7.84^{a}$ & $0.07^{a}$ & $5.02^{a}$ & $0.03^{b}$ & $99.97^{b}$ & 100 \\
\hline & & \multirow[t]{2}{*}{ Winter } & $\begin{array}{l}\text { Stock } \\
\left(\mathrm{mg} \cdot \mathrm{m}^{-}\right. \\
2)\end{array}$ & $\begin{array}{l}14.94 \\
\pm \\
13.24\end{array}$ & $\begin{array}{l}0.79 \\
\pm 0.19\end{array}$ & NA & $\begin{array}{l}0.84 \pm \\
0.00\end{array}$ & 16.57 & 59525.33 & 53453.18 \\
\hline & & & $\begin{array}{l}\text { Percent } \\
(\%)\end{array}$ & $\begin{array}{l}90.16 \\
\mathrm{a}\end{array}$ & $4.77^{\mathrm{a}}$ & NA & $5.07^{a}$ & $0.03^{b}$ & $99.97^{b}$ & 100 \\
\hline
\end{tabular}

Figures 

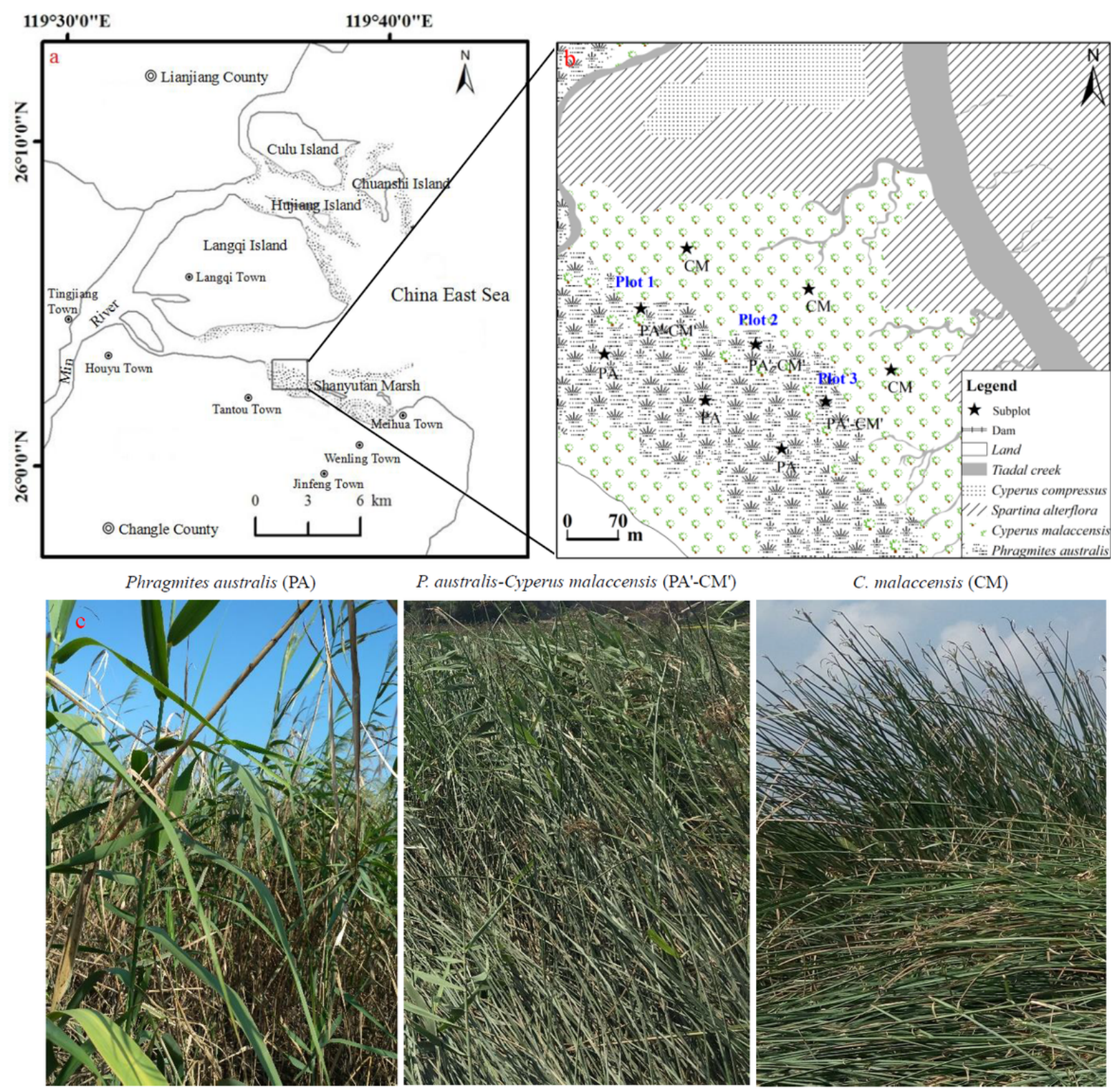

\section{Figure 1}

Sketch of the study region (a), the experimental plots (b), and the Phragmites australis, Cyperus malaccensis and P. australis-C. malaccensis communities (c). 


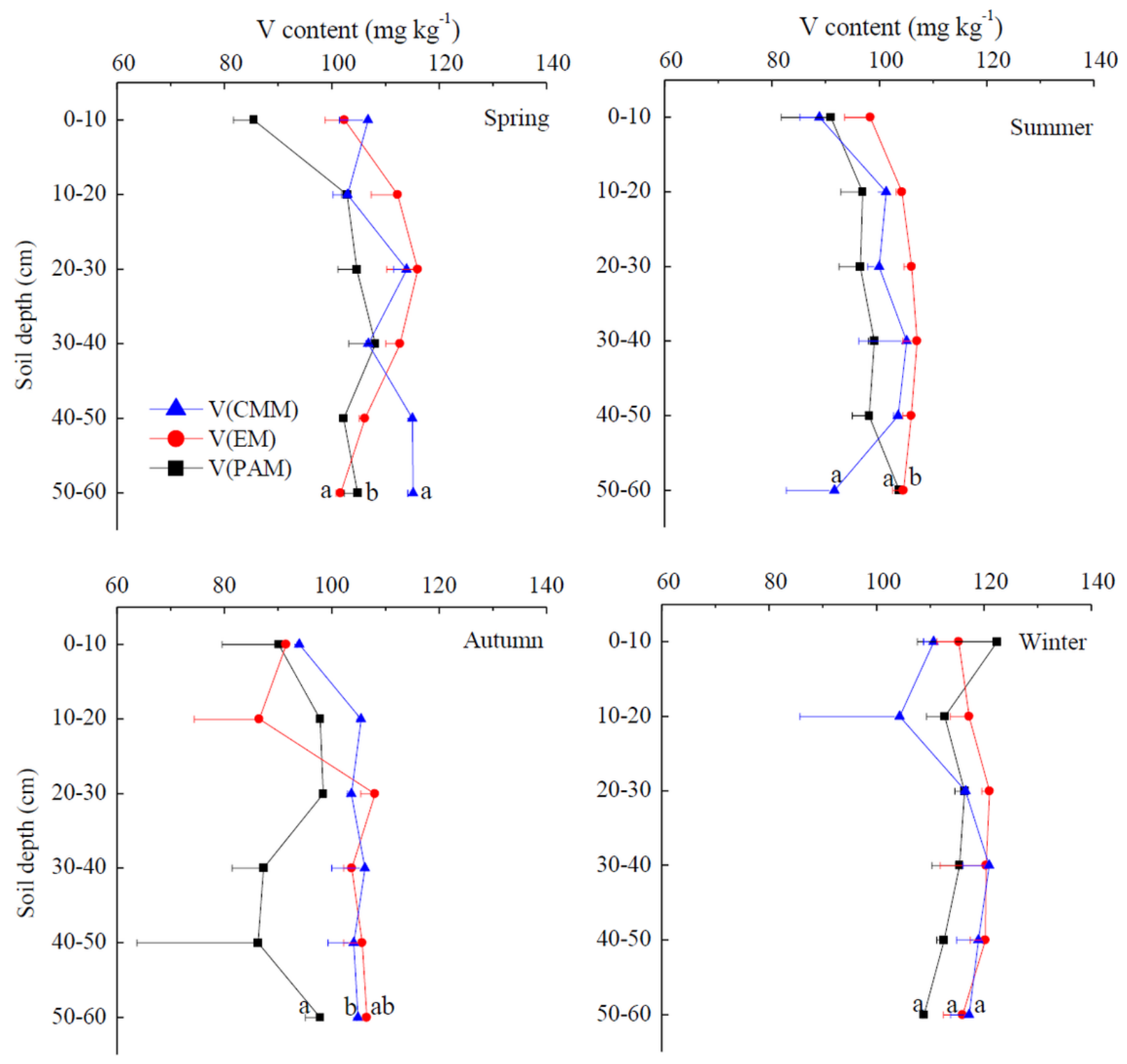

\section{Figure 2}

Temporal variations of vanadium content in soils of different marshes over all sampling seasons. PAM, Phragmites australis marsh; $\mathrm{EM}$, ecotonal marsh; and CMM, Cyperus malaccensis marsh. Values with the same letters are not significantly different at $p<0.05$. 

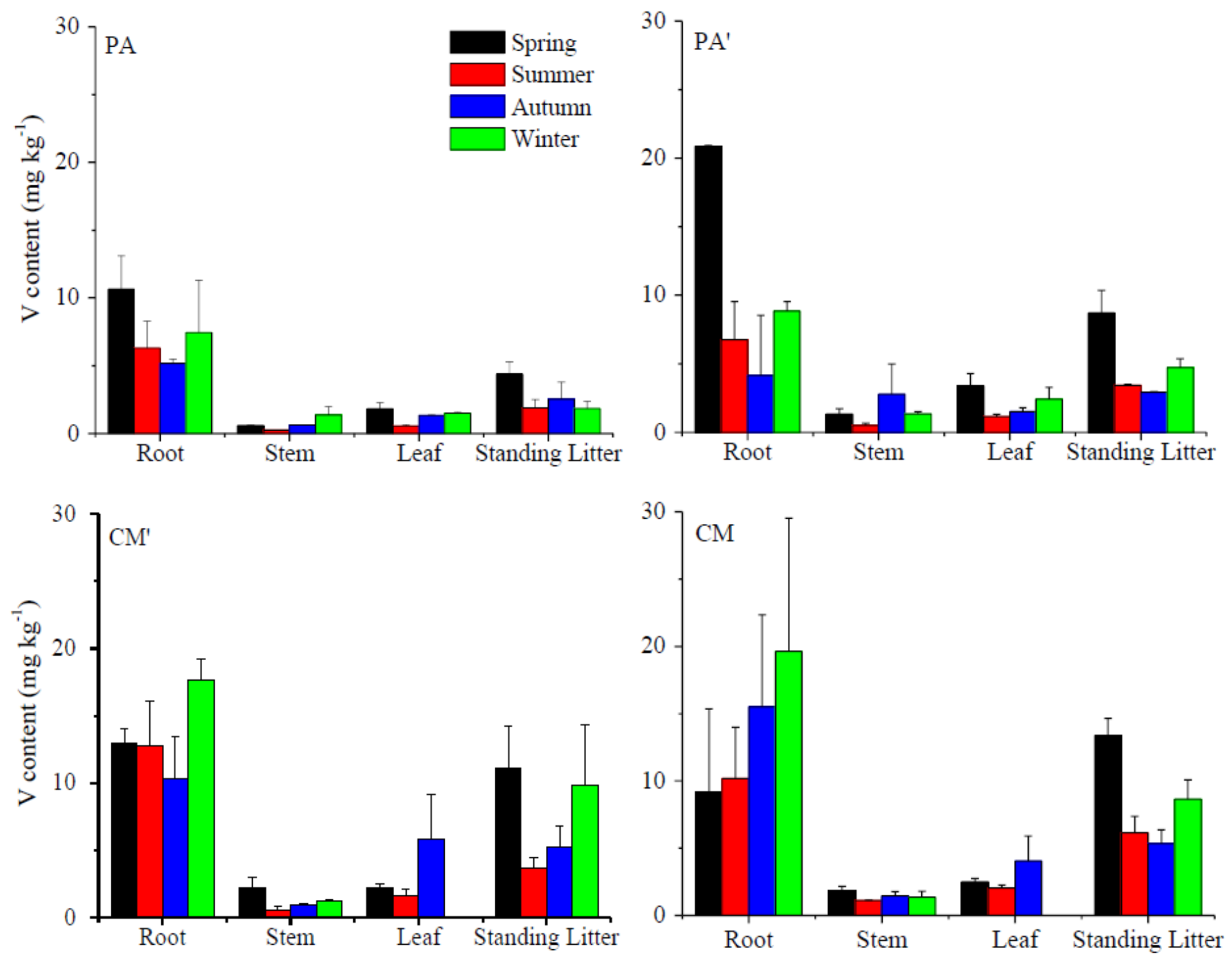

\section{Figure 3}

Temporal variations of vanadium content in tissues of different marsh plants. PA, Phragmites australis; CM, Cyperus malaccensis; PA', Phragmites australis in ecotonal marsh; and CM', Cyperus malaccensis in ecotonal marsh. 


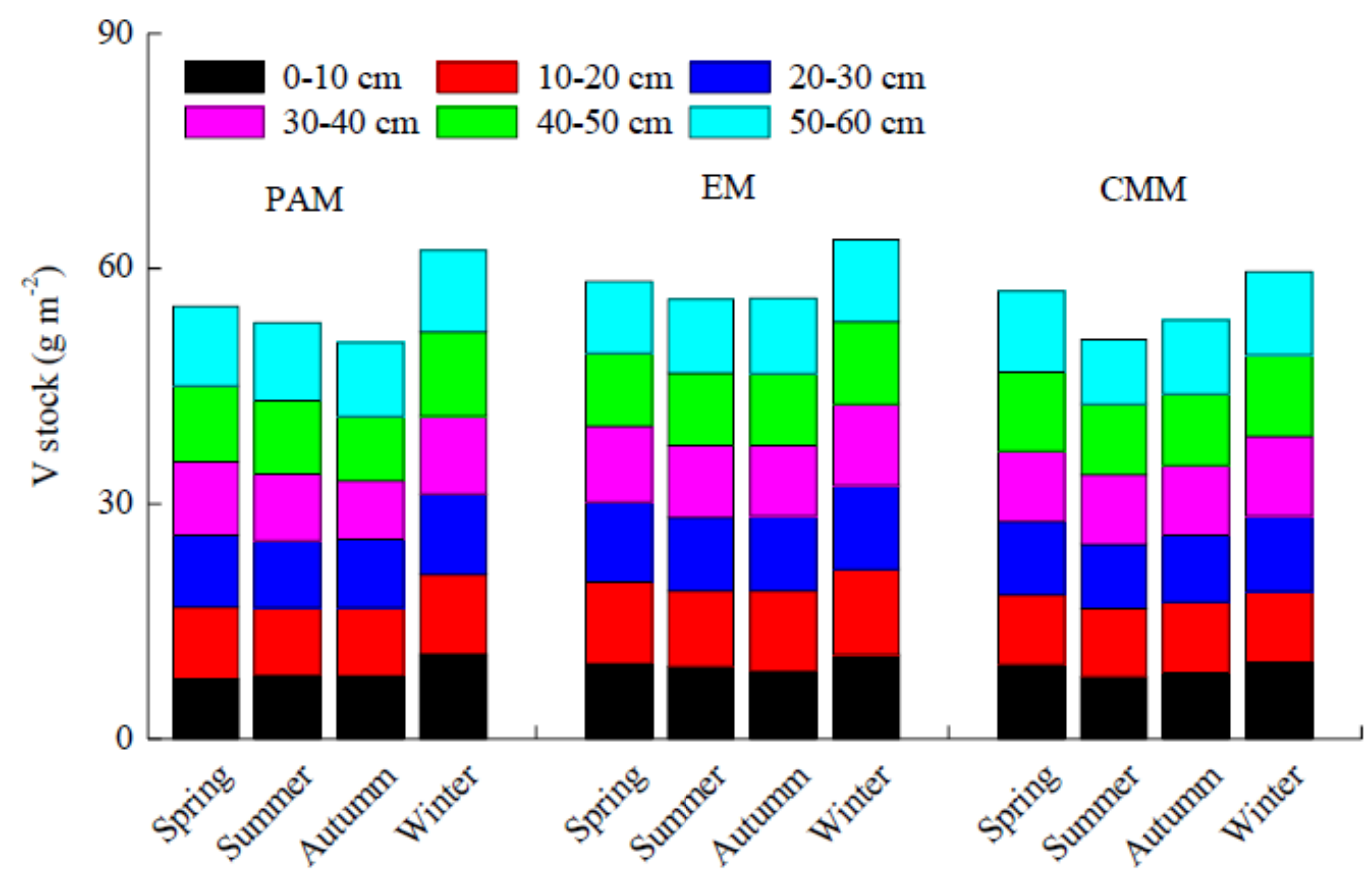

Figure 4

Stocks of vanadium in soils of different marshes. PAM, Phragmites australis marsh; EM, ecotonal marsh; and CMM, Cyperus malaccensis marsh 

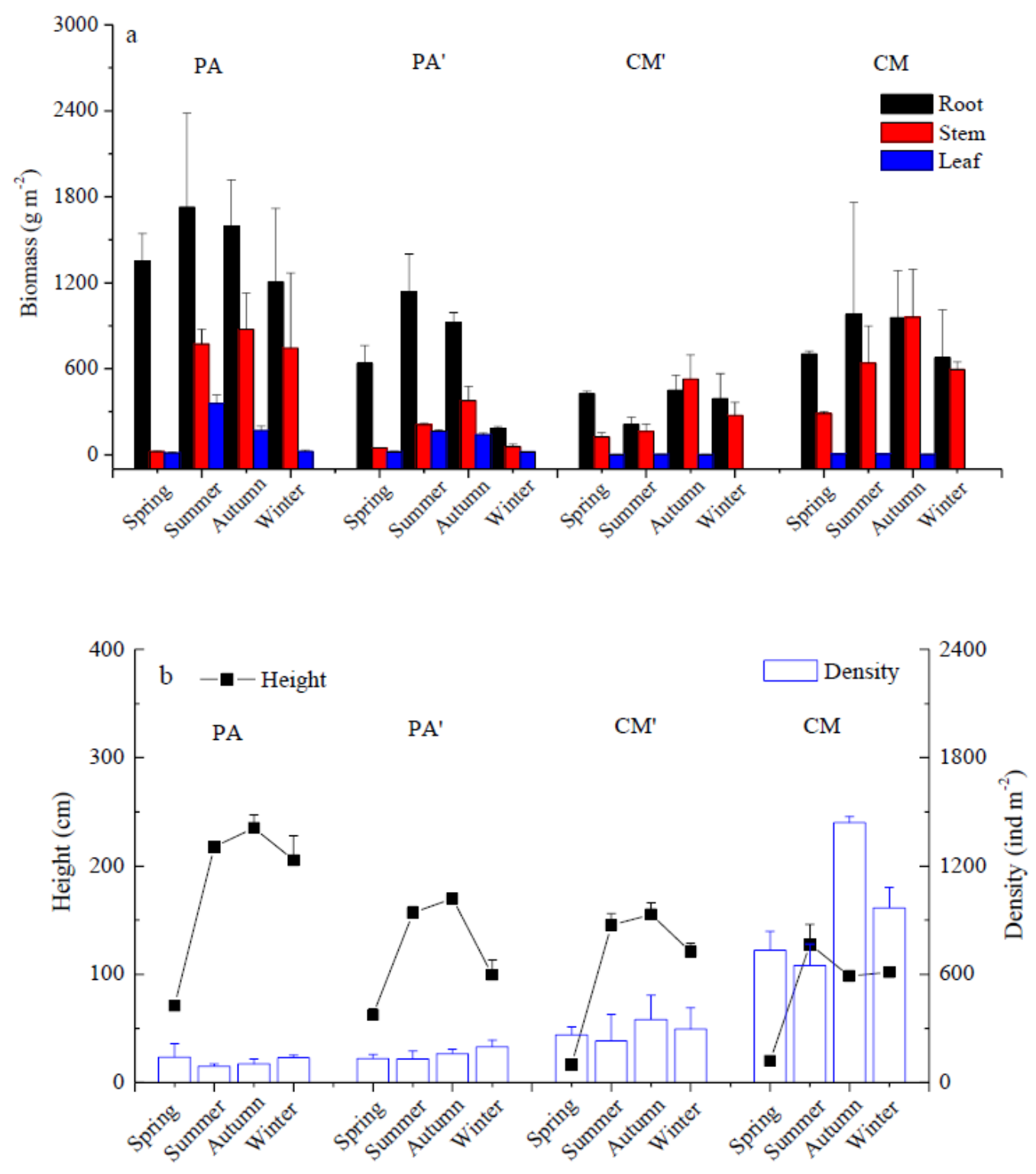

Figure 5

Temporal variations of aboveground and belowground biomasses (a), and heights and densities (b) of different marsh plants. PA, Phragmites australis; CM, Cyperus malaccensis; $\mathrm{PA}^{\prime}$, Phragmites australis in ecotonal marsh; and CM', Cyperus malaccensis in ecotonal marsh. 

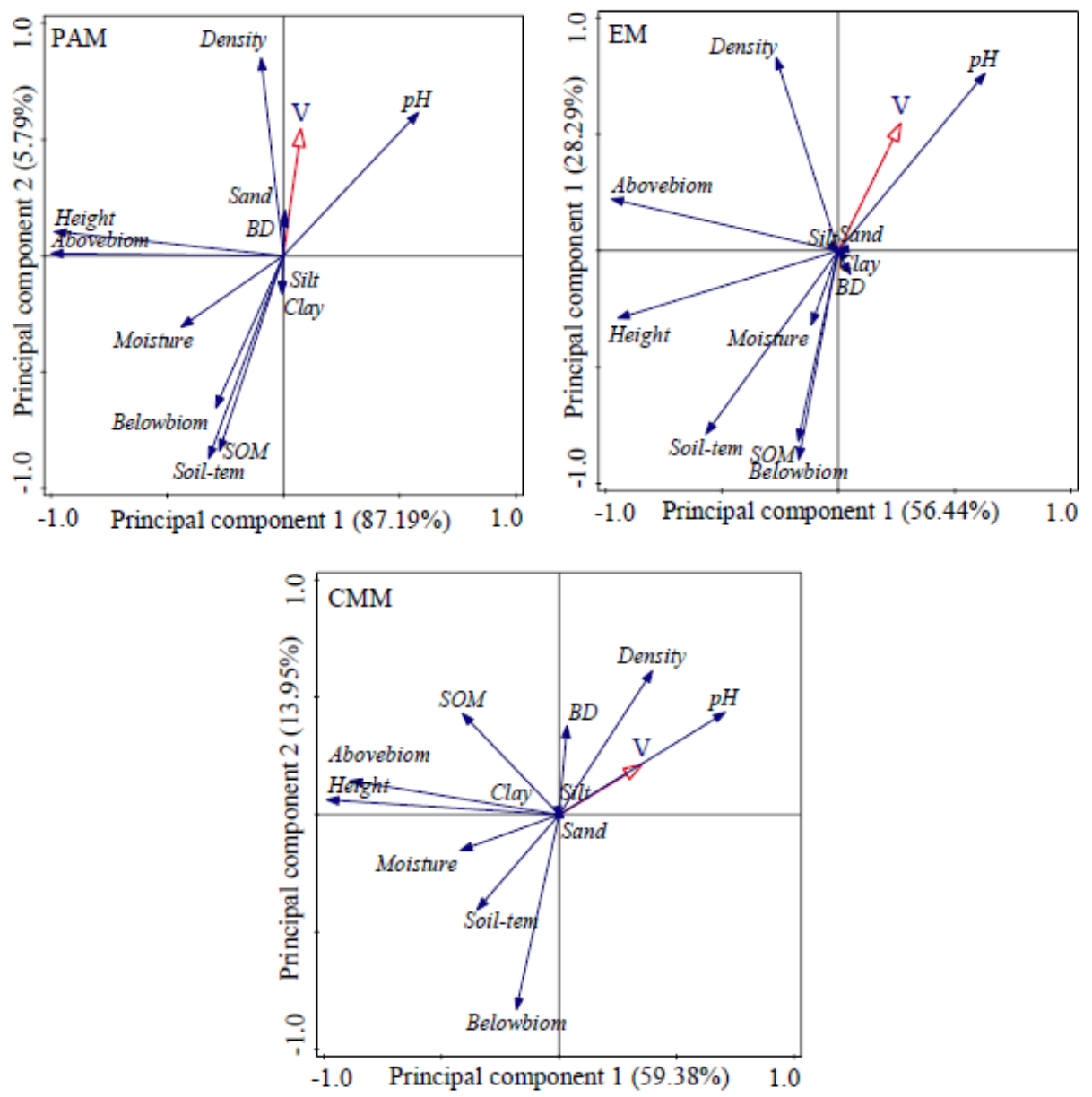

\section{Figure 6}

Principal component analyses for vanadium in soils and environmental variables in different marshes. PAM, Phragmites australis marsh; EM, ecotonal marsh; and CMM, Cyperus malaccensis marsh. Soil-tem, soil temperature; Belowbiom, belowground biomass; Abovebiom, aboveground biomass; BD, soil bulk density; and SOM, soil organic matter. 